\title{
ISLAM DAN TRADISI LOKAL DALAM PERSPEKTIF MULTIKULTURALISME
}

\author{
Oleh: M. Zainal Abidin*
}

\section{Abstract}

This paper tries to explore the compatibility of Islam toward the idea of multiculturalism. The discussion about the relationship between Islam and multiculturalism is very important in the context of plural country such as Indonesia, whether in religion side or in culture one. Knowing the significance of multiculturalism, the question is, how far the compability of Islam as mayor religion in this country with the idea of multiculturalism. As for the writer, there are two ways in making the compatibility of Islam toward the idea of multiculturalism: Firsthy, that we need to reinterpret the orthodox religion doctrine that always exclusive and oppressive. The reinterpretation is done in order religion may accept the local tradition wisdom. Secondly, that we always need to have a dialogue between Islam and the modernity. In multicultural perspective, it's clear that that the existence of local tradition will enrich the Islamic civilization. Each local tradition has the legal position before Islam. Here, the idea of "pribumisasi Islam" in Indonesia context as stated by Gus Dur is in the same way with the idea of multiculturalism.

مستخنص

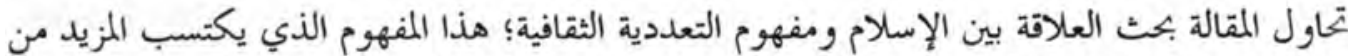

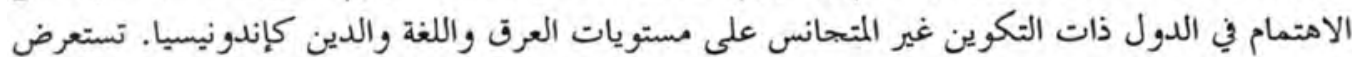

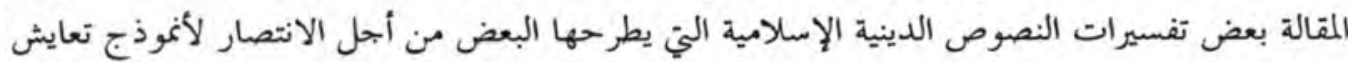

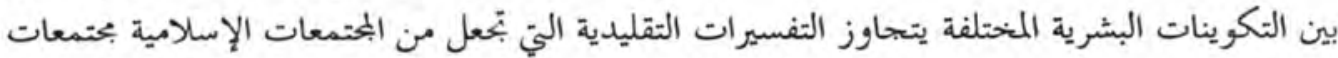

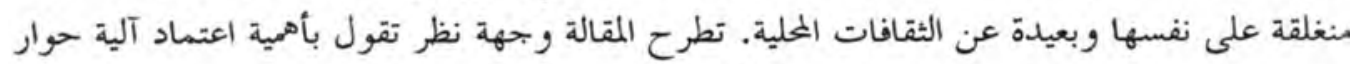

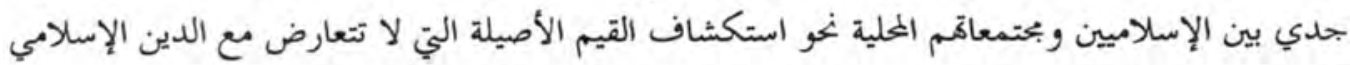
الذي هو دين الفطرة، محققين بذلك قول البي: إنما بعثت لأتمم مكارم الأخلاق.

Keywords: High Tradition, Low Tradition, Postkolonial, dan Multikulturalisme

Dosen Filsafat Islam Fakultas Ushuluddin IAIN Antasari Banjarmasin. Email: zayn@scientist.com 


\section{A. Pendahuluan}

Dalam diskursus mengenai relasi antara agama (baca: Islam) dan multikulturalisme di Indonesia, yang belakangan menjadi satu wacana yang ramai dibicarakan, ada satu problem mendasar yang tampaknya belum ada jawaban memuaskan, yakni sejauh mana kompatibilitas agama dalam mengapresiasi wacana multikulturalisme. Sampai saat ini, masih sering muncul dilema bagi agama dengan klaim universalitasnya untuk menerima kenyataan pluralitas budaya yang harus diposisikan pada level yang sejajar tanpa ada diskriminasi antara satu dengan lainnya, sebagaimana dikehendaki dalam ide multikulturalisme.

Sebagai sebuah pandangan yang menyatakan antidiskriminasi, gagasan multikulturalisme tampaknya cukup memberikan nilai positif terhadap realitas kultural yang sangat beragam di negeri ini. Terlebih di kala kultur yang beragam tersebut tidak jarang menjadi potensi yang rentan menimbulkan konflik antar elemenmasyarakat. Dalam hal ini, multikulturalisme dipandang mampu untuk memberikan apresiasi konstruktif terhadap segala bentuk keanekaragaman tradisi budaya, termasuk di dalamnya agama. ${ }^{1}$ Hanya persoalannya, jika berbagai kultur yang beragam bisa memperkaya kehidupan sosial, apakah agama juga bersedia menerima keragaman tradisi kultural sebagai pengayaan terhadap pemahaman keagamaan?

Sampai pada batas tertentu, jawaban agama terhadap gagasan multikulturalisme umumnya masih tampak ambigu. Hal ini karena agama memang sudah memiliki 'masalah' dengan keanekaragaman kultural. Dalam seluruh agama-agama besar dunia, sebagaimana disinyalir Amin Abdullah, ketegangan struktural selalu saja ada antara kepentingan untuk menjaga dan mempertahankan kesatuan agama (the unity of religion) dan keanekaragaman kultural (the cultural diversity), antarberbagai wilayah yang berbeda yang dijadikan tempat penyebaran agama. ${ }^{2}$

1 Dalam kajian sosial, agama sering dipandang sebagai bagian dari budaya. Maksud agama di sini, tentu saja bukan agama pada level normatif (normative religion), tetapi agama yang telah menyejarah (bistorical religion) sebagai buah dari interpretasi terhadap ajaran yang normatif (interpretative religion). Agama pada level interpretasi dan historis jelas tidak dapat dilepaskan dari budaya manusia. Tentang tiga persepsi mengenai Islam ini, lihat M. Dawam Rahardjo, Ensiklopedi al Qur'an: Tafsir Sosial Berdasarkan Konsep-Konsep Kunci, (Jakarta: Paramadina dan Jurnal Ulumul Qur'an, 1996), hal. 134.

2 Lihat Amin Abdullah, pengantar pada Zakiyuddin Baidhawy dan Mutohharun Jinan (eds.), Agama dan Pluralitas Budaya, (Surakarta: PSB-PS UMS, 2001), hal. xv. 
Ketegangan tersebut biasanya terjadi dalam menangkap dan memelihara pesan inti agama, termasuk praktik keagamaan. Maka, gagasan-gagasan seperti ortodoksi dan ortopraksi selalu diusung dalam merespons pertautan antara agama dan tradisi lokal suatu masyarakat. Gagasan ortodoksi adalah kepemilikan terhadap kebenaran agama (religious truth). Sedangkan ortopraksi, merupakan cara yang benar dari praktik dan pencapaian kebenaran dimaksud. Dalam konteks totalitas tradisi dan spektrum Islam, gagasan ortodoksi dan ortopraksi tersebut dapat dipahami sebagai kondisi keberadaan di jalan yang benar (straight path). Kegagalan menangkap dan melindungi pesan inti agama serta praktik keagamaan yang dianggap 'benar' tersebut pada gilirannya rentan memunculkan penilaian bahwa sebuah praktik keagamaan tidak absah.

Selain itu, problem lainnya, karena agama juga sering dipahami sebagai wilayah sakral, metafisik, abadi, samawi, dan mutlak. Bahkan, pada saat agama terlibat dalam urusan 'duniawi' sekalipun, hal itu tetap diproyeksikan sebagai penunaian urusan 'ukhrawi'. Berbagai agama, tentu saja, berbeda-beda dalam perkara cara dan berbagai aspek, namun agama-agama tersebut hampir seluruhnya memiliki sifat-sifat demikian.

Karena adaya unsur sakral dan mutlak tersebut, maka acapkali terasa sulit bagi suatu agama untuk dapat menoleransi atau hidup berdampingan dengan tradisi kultural yang dianggap bersifat duniawi (profan). Oleh karena itu, seringkali perjumpaan agama dan budaya lebih banyak memunculkan persoalan daripada manfaat. Dalam Islam misalnya, ada terma bid'ah yang akan "menghadang" mereka yang mencoba melakukan kompromi dan apresiasi terhadap budaya lokal, yang bukan budaya 'asli' Islam (baca: arab).

Secara sederhana, tulisan ini bermaksud melihat secara lebih saksama mengenai kompatibilitas Islam sebagai sebuah agama universal dengan tradisi lokal, dari sudut pandang multikulturalisme. Sebagai bahasan awal, untuk lebih memahami persoalan, akan dikemukakan terlebih dahulu perbincangan mengenai wacana agama dan multikulturalisme. Selanjutnya akan dikupas mengenai relasi Islam dengan tradisi lokal, yang kemudian dilanjutkan uraian terkait perspektif multikulturalisme terhadap relasi Islam dan tradisi lokal.

\section{B. Wacana Agama dan Multikulturalisme}

Gagasan multikulturalisme merupakan suatu isu yang relatif baru apabila dibandingkan dengan konsep pluralitas (plurality) maupun keragaman (diversity). Menurut Bikhu Parekh, baru sekitar tahun 1970-an gerakan multikultural muncul, 
pertama kali di Kanada dan Australia, kemudian di Amerika Serikat, Inggris, Jerman, dan lainnya. ${ }^{3}$

Dikarenakan isunya relatif baru, pembahasan tentangnya pun masih terbilang sedikit. Terlebih yang secara khusus melihat kompatibilitas antara agama atau Islam secara spesifik dengan gagasan multikulturalisme. Umumnya, gagasan tentang multikulturalisme banyak terkait dengan isu pendidikan. Beberapa tulisan yang membahas tema ini misalnya oleh Sonia Nieto, Affirming Diversity: The Sociopolitical contex of Multicultural Education; ${ }^{4}$ J.A. Banks and C.A.M. Banks (eds.), Multicultural Education: Issues and Perspectives; ${ }^{5}$ Francisco Hidalgo, Multicultural Education Lanscape for Reform in Twenty First Century. ${ }^{6}$ Sementara, tulisan yang sedikit mengkaitkan antara agama dan multikulturalisme misalnya oleh Lester R. Kurtz, Gods in the Global Village: the World's Religion in Sociological Perspectives, khususnya pada bab keenam. ${ }^{7}$

Di Indonesia sendiri tulisan-tulisan mengenai multikulturalisme mulai marak beberapa tahun terakhir dengan seringnya isu ini diangkat menjadi tema penelitian yang diperebutkan oleh berbagai perguruan tinggi dalam hibah penelitian oleh lembaga-lembaga pemerintah, yang melihat arti penting gagasan ini dalam konteks kehidupan bangsa dan negara Indonesia yang sangat multikultur dan juga multireligius.

Gagasan multikulturalisme, meski memiliki banyak kesamaan dengan konsep yang lebih dahulu lahir, yakni pluralitas (plurality) dan keragaman (diversity), namun memiliki perbedaan titik tekan. Konsep pluralitas mengandaikan adanya 'hal-hal yang lebih dari satu' (many); keragaman menunjukkan bahwa keberadaan yang lebih dari satu itu berbeda-beda, heterogen, dan bahkan tak dapat disamakan. ${ }^{8}$ Adapun

3 Sebagaimana dikutip Zubaedi, “Telaah Konsep Multikulturalisme dan Implimentasinya Dalam Dunia Pendidikan," dalam Hermenia Jurnal kajian Islam Interdisipliner Vol 3, Nomor 1, Januari-Juni 2004, hal. 3

4 Lihat Sonia Nieto, Affirming Diversity: The Sociopolitical Context of multicultural Education, (New York: Longman, Inc, 2000).

5 Lihat J.A. Banks and C.A.M. Banks (eds), Multicultural Education: Issues and Perspectives, (Boston: Allyn and Bacon, 1997).

6 Lihat Francisco Hidalgo, Multicultural Education Lanscape for Reform in Twenty First Century, (New Mexico: New Mexico State University, 2003).

7 Lihat Lester R. Kurtz, Gods in the Global Village: The World's Religion in Sociological Perspectives, (London: Pine Forge Press, 1995).

8 Secara radikal, multikulturalisme terkadang diartikan sebagai ideologi yang mengakui dan mengagungkan perbedaan dalam kesederajatan individual maupun secara kebudayaan. Lihat misalnya David Jary dan Julia Jary, "Multiculturalism”, Dictionary of Sociology, (New York: New Harper, 1991), hal. 319. 
multikulturalisme memberikan penegasan bahwa dengan segala perbedaannya itu mereka adalah sama di dalam ruang publik, sehingga dibutuhkan kesediaan menerima kelompok lain secara sama sebagai kesatuan, tanpa mempedulikan perbedaan budaya, etnik, jender, bahasa, ataupun agama.

Secara sederhana, multikulturalisme kemudian dipahami sebagai suatu konsep keanekaragaman budaya dan kompleksitas kehidupan di dalamnya. Multikulturalisme mengajak masyarakat dalam arus perubahan sosial, sistem tata nilai kehidupan yang menjunjung tinggi toleransi, kerukunan dan perdamaian bukan konflik atau kekerasan meskipun terdapat perbedaaan sistem sosial di dalamnya.

Multikulturalisme sendiri sering dikaitkan dengan upaya untuk merajut kembali hubungan antarmanusia yang belakangan selalu hidup dalam suasana penuh konflik. Ada sebuah kesadaran massif yang muncul, bahwa diperlukan kepekaan terhadap kenyataan kemajemukan, pluralitas bangsa, baik dalam etnis, agama, budaya, hingga orientasi politik. Multikulturalisme mengakui adanya politik universalisme yang menekankan harga diri semua manusia, serta hak dan kewajiban yang sama sebagai manusia. Tidak ada warga kelas satu (the first class) dan warga kelas dua (the second class), semua adalah sama (equal).

Melihat makna multikulturalisme sebagaimana disebut di atas, maka pembahasan agama dan multikulturalisme jelas menempati posisi yang signifikan bagi kehidupan bangsa Indonesia yang sangat plural, baik dari sisi agamanya, maupun keanekaragaman budayanya. Lebih dari itu, kesadaran multikulturalisme yang berbasiskan agama, jelas akan sangat kondusif, lebih produktif, dan menguntungkan bagi upaya mewujudkan Indonesia yang damai, jauh dari hingar bingar konflik yang hanya menyengsarakan wong cilik.

Pertanyaannya kemudian, apakah Islam sebagai agama dengan pemeluk paling besar di republik ini siap untuk mengamini dan sekaligus mendukung gagasan multikulturalisme, yang menolak diskriminasi terhadap tradisi yang beragam itu. Untuk mengetahui hal ini, pada bagian berikut ini akan dikemukakan sekitar pandangan Islam terhadap tradisi-tradisi lokal yang berbeda, untuk selanjutnya kemudian akan dilihat dari perspektif multikulturalisme.

\section{Pergumulan Islam dengan Tradisi Lokal}

Islam sebagai sebuah agama yang universal dan kosmopolit, apabila dilihat dari rentang perjalanan historisitasnya, - khususnya pada masa-masa kejayaanya (the golden age of Islam) dari abad ke-7 sampai dengan abad ke-13 Masehi - senantiasa 
bersikap terbuka terhadap pemikiran dan tradisi yang berbeda di luarnya, bahkan tak jarang memberikan apresiasi yang sangat bagus, dengan mengadopsi dan menjadikannya sebagai bagian yang integral dari Islam itu sendiri.

Refleksi dan manifestasi kosmopolitanisme Islam ini bahkan bisa dilacak dari sejarah paling awal kebudayaan Islam pada masa kehidupan Rasulullah hingga generasi-generasi sesudahnya, baik dalam format non material seperti konsep-konsep pemikiran, maupun yang material seperti seni arsitektur bangunan dan sebagainya. Dalam sirah nabi misalnya, Rasulullah saw. pernah diceritakan berkhotbah hanya dinaungi sebuah pelepah kurma. Kemudian tatkala komunitas kaum muslimin mulai bertambah banyak, dipanggillah seorang tukang kayu Romawi. Ia membuatkan untuk Nabi sebuah mimbar dengan tiga tingkatan yang dipergunakan untuk khotbah Jum'at dan munasabah-munasabah lainnya. ${ }^{9}$

Selain itu, cerita yang juga tak kalah popular, yakni dalam Perang Ahzab, Rasul dengan lapang dada menerima saran Salman al-Farisy untuk membuat parit (khandaq) di sekitar Madinah. Metode ini adalah salah satu metode pertahanan ala Persi. Para sahabat juga meniru adminsitrasi dan keuangan dari Persi, Romawi dan lainnya. Mereka tidak berkeberatan dengan hal itu selama menciptakan kemaslahatan dan tidak bertentangan dengan nash. ${ }^{10}$

Peradaban Yunani dengan filsafatnya yang kental juga sudah dikenal luas memiliki pengaruh kuat dalam pembangunan tradisi berfilsafat dalam Islam. Bahkan ada upaya besar dari para filosof muslim untuk memadukan antara agama (Islam) dengan filsafat sebagai dua hal yang berasal dari sumber yang sama, yakni Tuhan. ${ }^{11}$ Kejayaan peradaban yang pernah diraih Islam, akhirnya dipandang sebagai hasil dari kecerdikan para cendekiawan muslim dalam mengadopsi dan 'menjinakkan' pemikiran Yunani, yang kemudian secara jenius menerapkannya dalam bentuknya yang khas di dunia Islam. ${ }^{12}$

9 Lihat Yusuf al Qardhawi, Madkhal lî al-Dirâsah al-Islâmiyyah, (Beirut: Dar al-Fikr, 1993), hal. 253.

10 Lihat misalnya Badri Yatim, "Dari Mekah ke Madinah", dalam Taufik Abdullah, Ensiklopedi Tematis Dunia Islam, (Jakarta: PT. Ichtiar baru Van Hoeve, 2002), hal. 29-30.

11 Para Filosof Muslim klasik seperti al-Kindi, al-Farabi, Ibnu Sina, Ibnu Rusyd dan lain-lainnya sangat konsern dalam menampilkan pandangan keilmuan yang integralistik, tidak ada dikotomi antara agama dan ilmu (filsafat), keduanya berasal dari sumber yang sama dan karenanya tidak ada yang perlu dipertentangkan karenanya. Lihat misalnya Ibnu Rusyd, Falsafah Ibnu Rusyd: Fasl al-Maqâl wa alKasyfu, (Kairo: Maktabah al-Mahmudah al-Tijariah, 1968); lihat juga ulasan dalam M.M. Syarif (ed), $A$ History of Muslim Philosophy, (Wisbaden: Otto Harrassowitz, 1963) dan Sayyed Hossein Nasr and Oliver Leaman, History of Islamic Philosophy, Part I, (London and New York: Routledge, 1996).

12 Lihat misalnya Majid Fakhry, Sejarah Filsafat Islam: Sebuah Peta Kronologis, (Bandung: Mizan, 2001); lihat juga C.A. Qadir, Filsafat dan Ilmu Pengetabuan dalam Islam, (Jakarta: Yayasan Obor, 2002). 
Selain itu, yang lebih mencengangkan lagi, meski harus diakui bahwa unsur Arab memiliki keistimewaan di dalam Islam, ${ }^{13}$ akan tetapi sebagaimana dinyatakan Ibnu Khaldun, bahwa mayoritas ulama dan cendekiawan dalam agama Islam adalam 'ajam (non-Arab), baik dalam ilmu-ilmu syariat maupun ilmu-ilmu akal. Kalaupun di antara mereka orang Arab secara nasab, tetapi mereka 'ajam dalam bahasa, lingkungan pendidikan dan gurunya. ${ }^{14}$

Islam sebagai agama yang universal yang melintasi ruang dan zaman, kadangkala bertemu dengan tradisi lokal yang berbeda-beda. Ketika Islam bertemu dengan tradisi lokal, wajah Islam berbeda dari tempat satu dengan lainnya. Ajaran tentang tauhid (pengesaan Tuhan) adalah universal yang harus menembus batasbatas geografis dan kultural yang tidak dapat ditawar-tawar lagi. Sementara itu ekspresi kebudayaan dalam bentuk tradisi, cara berpakaian, arsitektur, sastra dan lain-lain memiliki muatan lokal yang tidak selalu sama.

\section{Perspektif Multikulturalisme terhadap Relasi Islam dan Tradisi Lokal}

Dalam perspektif multikulturalisme, tampak jelas bahwa keberadaan tradisi lokal dipandang sangat penting dalam memperkaya khazanah peradaban keislaman. Masing-masing tradisi lokal itu berada pada posisi yang absah untuk diakui keberadaannya sebagai bagian dari Islam, yang posisinya setara, sederajat. Karena itu, gagasan semisal pribumisasi Islam dalam konteks Indonesia sebagaimana

13 Menurut Imarah, adanya hubungan yang erat antara Islam sebagai agama dengan unsur Arab dikarenakan: (1) Islam diturunkan kepada Muhammad bin Abdullah, seorang Arab. Juga Mu'jizat terbesar agama ini, Al-Qur'an, didatangkan dengan bahasa Arab yang jelas (al-mubîn), yang ketinggian sastranya dapat mengungguli para sastrawan terkemuka Arab sepanjang sejarah. Sebagaimana memahami dan menguasai Al-Qur'an sangat sulit dengan bahasa apapun selain Arab. Implikasinya, Islam menuntut pemeluknya jika ingin menyelami dan mendalami makna kandungan Al-Qur'an, maka hendaknya 'mengarabkan' diri; (2) dalam menyiarkan dakwah Islam yang universal, bangsa Raba berada di garda depan, dengan pimpinan kearaban Nabi dan Al-Qur'an. Kebangkitan realita Arab dari segi sebab turunnya wahyu dengan peran sebagai buku catatan interpretatif terhadap AlQur'an dan lokasi dimulainya dakwah di jazirah Arab sebagai ‘peleton pertama terdepan' dibarisan tentara dakwahnya; (3) Jika agama-agama terdahulu mempunyai karakteristik yang sesuai dengan konsep lokal, kondisional dan temporal, pada saat Islam berkarakteristikkan universal dan mondial, maka posisi mereka sebagai 'garis terdepan' agama Islam adalah menembus batas wilayah mereka. Lihat Muhammad Imarah, Al-Islâm wa al-'Urûbah, (Kahirah: Al Haihal Al Mashriyyah Al 'Ammah Lil Kitab, 1996), hal. 11-12.

14 Ibnu Khaldun, Muqaddimah Ibnu Khaldun, (Beirut: Dar al-Fikr, 1989), hal. 543. 
diungkapkan Gus Dur menjadi sesuatu yang sealur dan seirama dengan ide multikulturalisme. ${ }^{15}$

Memang terkadang persoalan muncul, yakni ketika Islam yang pada suatu masa dan waktu yang cukup lama, berkelindan dengan budaya lokal setempat (Arab, Persia), kemudian dipandang menjadi sesuatu yang sifatnya universal, dan hendak diterapkan secara general di seluruh kawasan Islam. Maka, muncullah kemudian istilah Islam resmi dengan sebutan high tradition yang berhadapan dengan Islam rendah atau Islam popular sebagai low tradition. ${ }^{16}$ Konflik pun muncul, tatkala Islam resmi bermaksud menjalankan misi pemurnian (purifikasi) yang sarat dengan nuansa pemaksaan terhadap Islam popular, yang dianggap menyimpang dari yang seharusnya.

Sebenarnya konflik ini bisa diatasi, apabila Islam resmi yang diasumsikan sebagai Islam popular bisa mengakomodasi tradisi lokal, yang hal ini telah dipraktikkan dengan cukup baik sepanjang sejarah Islam. Untuk itu, perlu ada kesepahaman bahwa antara Islam resmi dan Islam popular tidak perlu harus dipertentangkan satu sama lain.

Ada beberapa perspektif yang dapat dikemukakan dalam mengatasi persoalan-persoalan yang muncul dalam hubungan antara Islam dengan tradisi lokal. Pertama, terkait pola hubungan high tradition dan low tradition, tawaran wacana poskolonial bisa menjadi alternatif yang patut dipertimbangkan. Dalam wacana poskolonial misalnya, ada beberapa kritikan yang bisa diadaptasi. (1) paradigma pusat dan pinggir atau resmi dan tak resmi menurut perspektif

15 Bagi Abdurrahman Wahid atau lebih dikenal Gus Dur, Pribumisasi Islam bermakna Islam sebagai ajaran yang normatif berasal dari Tuhan diakomodasikan ke dalam kebudayaan yang berasal dari manusia tanpa kehilangan identitasnya masing-masing. Arabisasi atau proses mengidentifikasi diri dengan budaya Timur Tengah adalah tercerabutnya kita dari akar budaya kita sendiri. Lebih dari itu, Arabisasi belum tentu cocok dengan kebutuhan. Pribumisasi bukan upaya untuk menghindarkan timbulnya perlawanan dari kekuatan budaya-budaya setempat, akan tetapi justeru agar budaya itu tidak hilang. Karena itu, inti pribumisasi adalah kebutuhan bukan untuk menghindari polarisasi antara agama dengan budaya, sebab polarisasi demikian memang tidak terhindarkan. Lihat Abdurrahman Wahid, Pergulatan Negara, Agama, dan Kebudayaan, (Jakarta: Desantara, 2001), hal. 111.

16 Klasifikasi ini merujuk pada Ernest Gellner. Menurut Gellner, tradisi tinggi adalah Islam resmi atau Islam yang dianggap lebih dekat kepada kitab suci dan umumnya tumbuh di perkotaan. Tradisi tinggi, meskipun tidak dapat dilaksanakan dalam waktu tertentu, tetap dan terus akan diperjuangkan untuk dilaksanakan, suatu saat nanti. Maka, ketika budaya-budaya lokal -yang merupakan perwujudanm tradisi rendah-terancam oleh kemerosotan, kaum muslim dengan gampang melompat ke arah tradisi tinggi dalam rangka mengatasi krisis yang tengah mereka hadapi. Lihat M. Imaduddin dkk, "Islam Pribumi: Mencari Wajah Islam Indonesia,” dalam Tashwirul Afkar Edisi No. 14 Tahun 2003, hal. 12. 
poskolonial adalah wacana kolonial, yang menjadikan relasi kuasa sebagai paradigma interaksi dan dialektika. Dalam perspektif poskolonial, yang pusat haruslah menyadari bahwa dia dapat menjadi pusat karena ada yang pinggir. Karenanya yang pinggir, bukan untuk disingkirkan bahkan dihanguskan; (2) poskolonial akan melihat konteks kekuasaan ketika suatu paham keagamaan itu lahir. Boleh jadi jargon seperti kembali pada Al-Qur'an dan Sunnah lahir tidak saja memiliki konteks teologis, tetapi sekaligus konteks hubungan kekuasaan yang terjadi pada saat itu; (3) sebagai pembawa wacana tanding, poskolonial akan senantiasa melihat peluang dan celah relativisme atas semua yang telah dikanonkan. Lebih jauh dari itu, dekanonisasi menjadi jalan strategis yang ditempuh untuk membuka selebar-selebarnya peluang nalar kritik dalam membangun tradisi pemikiran dan mencegah tertutupnya kembali pintu ijtihad. ${ }^{17}$

Kedua, terkait kompatibilitas Islam dengan keanekaragaman tradisi lokal dengan perspektif multikulturalisme, maka dibutuhkan pendekatan yang tidak semata teologis (normatif), tetapi juga sejarah (historis). M. Arkoun menyebut pendekatan ini sebagai taqlîdiyyah-taifiyyah dan pendekatan târikhiyyahilmiyyah. Pendekatan taqlidiyyah-taifiyyah lebih bersifat eksklusif dan lebih menekankan finalitas dan pemutlakan suatu ajaran agama. Sedangkan pendekatan târikhiyyah-ilmiyyah lebih bersifat aposteriori, empiris, dan open ended, dialogis dan toleran tanpa meninggalkan normativitas ajaran agama yang dipeluknya sendiri. ${ }^{18}$

Selanjutnya, dalam upaya membangun hubungan sinergi antara multikulturalisme dan agama, setidaknya ada dua hal yang bisa dilakukan: (1) perlunya penafsiran ulang atas doktrin-doktrin keagamaan ortodoks yang sementara ini dijadikan dalih untuk bersikap eksklusif dan opresif. Penafsiran ulang itu harus dilakukan sedemikian rupa, sehingga agama bisa lebih bersikap reseptif terhadap kearifan tradisi lokal; (2) perlunya terus mendialogkan agama dengan gagasan-gagasan dan tantangan modernitas. Saat ini, umat beragama memasuki suatu fase sejarah baru di mana mereka harus mampu

17 Lihat Paryanto "Islam, Akomodasi Budaya dan Poskolonial", dalam Zakiyyudin Baidhawy dan Mutohharun Jinan, Agama dan Pluralitas Budaya, (Surakarta: PSB-PS UMS, 2001), hal. 65-66.

18 Lihat M. Amin Abdullah, Dinamika Islam Kultural: Pemetaan Atas Wacana Keislaman Kontemporer, (Bandung: Mizan, 2000), hal. 116. 
beradaptasi dengan peradaban-peradaban besar yang tidak didasarkan pada agama, seperti peradaban Barat modern. Ide-ide dan teori-teori sekular tidak mungkin bisa dihindari dan diabaikan begitu saja. Dan ini merupakan tugas paling menantang yang dihadapi kaum muslim pada zaman modern ini. ${ }^{19}$

Melihat pola hubungan antara agama universal dan tradisi lokal, setidaknya ada dua hal yang bisa dikemukakan. Pertama, sebuah agama universal (semisal Islam dan Kristen) memang sangggup memberikan lompatan kesadaran yang semula terpasung pada wilayah lokal menuju kesadaran universal, ${ }^{20}$ namun tidak dapat memberikan petunjuk menghadapi persoalan-persoalan lokal. Kesejarahan agama universal yang terkait dengan kelokalannya masing-masing membuat agama universal pada beberapa sisi tetap menjadi milik wilayah asalnya masing-masing. Wilayah asal agama universal bukanlah wilayah prototipe bagi seluruh wilayah penyebarannya. Universalisasi segala unsur agama dengan demikian tidak dapat diberlakukan, kecuali jika wilayah asal agama merupakan wilayah prototipe semisal dunia idea Plato yang memuat segala hal ihwal kehidupan di wilayah mana pun.

Kedua, tradisi lokal tidak pernah sepenuhnya bisa dilenyapkan. Ada bagianbagian dari tradisi lokal (ikon atau konsep) yang terus bertahan dipelihara dan tidak tergantikan oleh ajaran universal. Dengan cara ini dapat dikemukakan bahwa ajaran universal diapropriasi untuk mengisi ruang konsepsi yang pada tradisi lokal masih bersifat terbatas, sedangkan cara-cara hidup di ruang lokal tetap menggunakan tradisi lama.

19 Seorang pemikir muslim, Shabbir Akhtar mengungkapkan bahwa kita tidak mungkin menemukan bukti yang lebih baik tentang kelumpuhan intelektual para pengikut muhammad sekarang ini selain kegagalan mereka dalam memberikan respons yang memadai terhadap tantangan-tantangan modernitas sekuler. Umat muslim modern, sebagai sekelompok masyarakat, secara memalukan tidak merenungkan tantangan-tantangan modernitas sekuler tersebut, seakan-akan berpikir bahwa Allah telah memikirkan segala-galanya untuk hamba-hamba-Nya. Meskipun Islam tidak kekurangan para apologis (pembela agama) atau teoritikus agama, secara bersama-sama mereka telah gagal memberikan respons yang bernas dan mendasar terhadap modernitas. Lihat Shabbir Akhtar, Islam Agama Semua Zaman (Faith for All Seasons: Islam and western Modernity), Penerjemah Rusdi Djana, (Jakarta: Pustaka Zahra, 2002), hal. 7.

20 Menurut Bob Heffner dalam “Antropologi Konversi”, perpindahan agama merupakan salah satu jalan bagi suatu bangsa untuk menjadi suatu peradaban besar. Sebagai contoh ujar Heffner, seseorang yang mula-mula adalah anggota dari suku terasing di pedalaman, kemudian dia memeluk agama Kristen atau Islam, maka orang itu seperti meloncat dari suatu lingkaran kebudayaan yang sempit dan masuk ke dalam 'gerbong' peradaban besar yang pengaruhnya melintas batas nasionalitas. Lihat Ulil Abshar-Abdalla, 'Menimbang Islam Pribumi," dalam Tashwirul Afkear Edisi No. 14 Tahun 2003, hal. 129. 
Sebagai pamungkas dari tulisan ini, menarik untuk mencermati pernyataan Munir Mulkhan dalam suatu wawancara bahwa sejatinya Islam itu sendiri lahir sebagai produk lokal yang kemudian diuniversalisasikan dan ditransendensi, sehingga kemudian menjadi Islam universal. ${ }^{21}$ Dalam konteks Arab, yang dimaksud dengan Islam sebagai produk lokal adalah Islam yang lahir di Arab, tepatnya daerah Hijaz, dalam situasi Arab dan pada waktu itu ditujukan sebagai jawaban terhadap persoalanpersoalan yang berkembang di sana. Islam Arab tersebut terus berkembang ketika bertemu dengan budaya dan peradaban Persia dan Yunani, sehingga kemudian Islam mengalami proses dinamisasi kebudayaan dan peradaban.

Selanjutnya, walaupun kita yakin bahwa Islam itu wahyu Tuhan yang universal, yang gaib, namun akhirnya ia dipersepsi oleh si pemeluk sesuai dengan pengalaman, problem, kapasitas intelektual, sistem budaya, dan segala keragaman masing-masing pemeluk di dalam komunitasnya. Dengan demikian, memang justru kedua dimensi ini perlu disadari yang di satu sisi Islam sebagai universal, sebagai kritik terhadap budaya lokal, dan kemudian budaya lokal sebagai bentuk kearifan masing-masing pemeluk di dalam memahami dan menerapkan Islam itu.

\section{E. Penutup}

Watak Islam sebagaimana dinyatakan dalam Al-Qur'an adalah agama yang sempurna (Q.S. 5: 3). Kesempurnaan ini harus dilihat pada prinsip-prinsip dasar yang terdapat pada Islam yang sangat lentur dan kemampuannya untuk terbuka dengan peradaban lain di luar Islam. Sejarah Islam telah memperlihatkan suatu dinamika internal dan eksternal dalam memberikan warna terhadap peradaban manusia.

Munculnya Islam sebagai satu peradaban, bukanlah peristiwa yang bersifat kebetulan, tapi merupakan suatu rangkaian proses yang dilakukan secara sistematis dalam menghadapkan doktrin Islam dengan suatu setting sejarah. Dalam proses demikian, jelas sekali peran umat Islam dalam melakukan perambahan intelektual, yang kemudian melahirkan pemikiran Islam dalam upaya memberikan respon terhdap berbagai permasalahan atau menjadikan Islam sebagai kekuatan sejarah.

Islam adalah agama yang terbuka terhadap pemikiran di luarnya. Dari sejarah bisa diketahui bahwa begitu keluar dari Jazirah Arabia dan mendapati kekayaan

21 Lihat wawancara Ulil dengan Abdul Munir Mulkhan dalam www.islamlib.com, diakses pada 25 Oktober 2008. 
peradaban dan budaya yang lebih tinggi, tanpa banyak membuang waktu, mengadaptasi dan menjadikannya seperti milik sendiri. Keterbukaan terhadap peradaban lain dan rasa percaya diri yang kuat terhadap kemampuan menalar tanpa taqlid buta, merupakan kunci penting dalam melahirkan produk pemikiran.

Ajaran normatif dan sejarah Islam yang sangat terbuka dan mengapresiasi tradisi lokal kiranya bisa menjadi modal bagi umat Islam dalam memasuki era multikulturalisme. Setiap manusia, apa dan bagaimanapun tradisinya, menempati posisi yang sejajar yang patut dihargai dan diakui keberadaannya. Oleh karenanya, bagi Islam, multikulturalisme malah menjadi celah dalam upaya mewujudkan visi Islam sebagai rabmatan li al-â'lamîn.

\section{DAFTAR PUSTAKA}

Abdalla, Ulil Abshar. 2003. 'Menimbang Islam Pribumi," dalam Tashwirul Afkar Edisi No. 14 Tahun.

Abdullah, M. Amin. 2000. Dinamika Islam Kultural: Pemetaan Atas Wacana Keislaman Kontemporer. Bandung: Mizan.

Abdullah, Taufik. 2002. Ensiklopedi Tematis Dunia Islam. Jakarta: PT. Ichtiar baru Van Hoeve.

Akhtar, Shabbir. 2002. Islam Agama Semua Zaman (Faith for All Seasons: Islam and western Modernity). Penerjemah Rusdi Djana. Jakarta: Pustaka Zahra.

Baidhawy, Zakiyuddin dan Mutohharum Jinan (eds.). 2001. Agama dan Pluralitas Budaya. Surakarta: PSB-PS UMS.

Banks, J.A. and C.A.M. Banks (eds). 1997. Multicultural Education: Issues and Perspectives. Boston: Allyn and Bacon.

Fakhry, Majid. 2001. Sejarah Filsafat Islam: Sebuah Peta Kronologis. Bandung: Mizan. Hidalgo, Francisco. 2003. Multicultural Education Lanscape for Reform in Twenty First Century. New Mexico: New Mexico State University.

Imaduddin, M. dkk. 2003. "Islam Pribumi: Mencari Wajah Islam Indonesia," dalam Tashwirul Afkar Edisi No. 14 Tahun.

Jary, David dan Julia Jary. 1991. "Multiculturalism", Dictionary of Sociology. New York: New Harper. 
Khaldun, Ibnu. 1989. Muqaddimah Ibnu Khaldun. Beirut: Dar al-Fikr.

Kurtz, Lester R. 1995. Gods in the Global Village: The World's Religion in Sociological Perspectives. London: Pine Forge Press.

Muhammad Imarah. 1996. Al Islam wa al Urubah. Kahirah: al-Haihal al-Mashriyyah al-'Ammah Lil Kitab.

Nasr, Sayyed Hossein and Oliver Leaman. 1996. History of Islamic Philosophy. Part I. London and New York: Routledge.

Nieto, Sonia. 2000. Affirming Diversity: The Sociopolitical Context of Multicultural Education. New York: Longman, Inc.

Qadir, C.A. 2002. Filsafat dan Ilmu Pengetahuan dalam Islam. Jakarta: Yayasan Obor. Al-Qardhawi, Yusuf. 1993. Madkhal li al-Dirâsah al-Islâmiyyah. Beirut: Dar al-Fikr.

Rahardjo, M. Dawam. 1996. Ensiklopedi al-Qur'an: Tafsir Sosial Berdasarkan KonsepKonsep Kunci. Jakarta: Paramadina dan Jurnal Ulumul Qur'an.

Roy, Muhammad. 2004. Ushul Fiqh Madzhab Aristoteles: Pelacakan Logika Aristoteles dalam Qiyas Ushul Fiqh. Yogyakarta: Safiria Insania Press.

Rusyd, Ibnu. 1968. Falsafah Ibnu Rusyd: Fasl al-Maqâl wa al-Kasyfu. Kairo: Maktabah al-Mahmudah al-Tijariah.

Syarif, M.M. (ed). 1963. A History of Muslim Philosophy. Wisbaden: Otto Harrassowitz.

Wahid, Abdurrahman. 2001. Pergulatan Negara, Agama, dan Kebudayaan. Jakarta: Desantara.

Zubaedi. 2004. “Telaah Konsep Multikulturalisme dan Implimentasinya Dalam Dunia Pendidikan," dalam Hermenia Jurnal Kajian Islam Interdisipliner Vol 3, Nomor 1, Januari-Juni. 